Original Article

\title{
Growth performance and survivability of the Asian seabass Lates calcarifer(Bloch, 1790) reared under hyper-saline, hypo-saline and freshwater environments in a closed aquaculture system
}

\author{
Desempenho de crescimento e sobrevivência do robalo asiático Lates calcarifer \\ (Bloch, 1790) criado em ambientes hipersalinos, hipossalinos e de água doce em um \\ sistema de aquicultura fechado
}

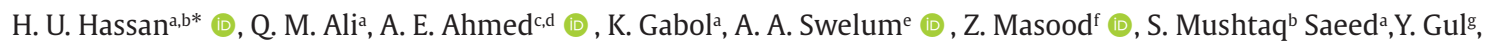
S. Rizwan ${ }^{\text {h }}$ T. Zulfiqari and M. A. M. Siddiquej (1)

aUniversity of Karachi, Department of Zoology, Karachi, Pakistan

${ }^{b}$ Ministry of National Food Security and Research, Fisheries Development Board, Karachi, Pakistan

'King Khalid University, College of Science, Biology Department, Abha, Saudi Arabia

dSouth Valley University, Faculty of Veterinary Medicine, Department of Theriogenology, Qena, Egypt

'Faculty of Veterinary Medicine, Zagazig University, Department of Theriogenology, Sharkia 44519, Egypt

fSBK Women University Quetta, Department of Zoology, Balochistan, Pakistan

${ }^{g}$ Government College Women University, Department of Zoology, Faisalabad, Pakistan

hjinnah University for Women, Karachi, Pakistan

iUniversity of Okara, Department of Zoology, Okara, Pakistan

${ }^{j}$ Noakhali Science and Technology University, Department of Oceanography, Noakhali, Bangladesh

\begin{abstract}
Salinity is one of the most critical environmental parameters regarding fish physiology, modifying food intake and growth performance in many fish species. The present study has investigated the effects of different salinity levels on growth performance, feeding and survival of Asian seabass Lates calcarifer juveniles. Asian seabass juveniles were reared at 0 (T1), 5 (T2), 22 (T3), 36 (T4), and 42 (T5) ppt salinity. Approximately eight hundred thirty fish individuals with an average weight of $1.24 \pm 0.52 \mathrm{~g}$ were randomly distributed (166 fish/Tank) in 5 concrete tanks (each tank $30 \times 6 \times 4 \mathrm{ft}$, volume $19,122 \mathrm{~L}$ ) for forty days. Juveniles were initially fed $42 \%$ crude protein-containing diets at a rate of $6 \%$ of their body weight per day. The results showed that salinity level had a significant effect on the weight gain (WG), average daily weight gain (ADWG), specific growth rate (SGR), feed conversion ratio (FCR), survival rate (SR), total biomass and health indices $(\mathrm{p}<0.05)$. The highest WG $(39.11 \pm 1.49 \mathrm{~g})$, ADWG $(1.00 \pm 0.12$ g), SGR $\left(8.74 \pm 0.03 \% \mathrm{~d}^{-1}\right)$ and lowest FCR $(0.96 \pm 0.20)$ were observed with T3 treatment, which was significantly higher compared to other treatment groups $(\mathrm{p}<0.05)$. Among the health indices, the highest hepatosomatic index and viscerosomatic index were found with $\mathrm{T} 3$ treatment, significantly higher than the other groups ( $\mathrm{p}<0.05)$. No significant differences were found among the treatments in terms of survival rate $(p>0.05)$, but the maximum survival rate $(98.89 \pm 0.0 \%)$ was observed in the T3 and T2 treatments. The maximum level of crude proteins $(19.99 \pm 1.4 \%)$ was found in the whole-body biochemical composition of Asian seabass juveniles in the T3 treatment group. The second-order polynomial regression showed that 20 ppt salinity is optimum for the best growth of Asian seabass. Thus, the present study recommends 20 to 36 ppt salinity for the commercial farming of Asian seabass under a closed aquaculture system.
\end{abstract}

Keywords: Lates calcarifer, aquaculture, effects of salinity, survival.

\section{Resumo}

A salinidade é um dos parâmetros ambientais mais críticos em relação à fisiologia dos peixes, modificando a ingestão de alimentos e o desempenho de crescimento em muitas espécies. O presente estudo investigou os efeitos de diferentes níveis de salinidade no desempenho de crescimento, alimentação e sobrevivência de jovens espécies de robalos asiáticos Lates calcarifer, as quais foram criadas sob salinidade 0 (T1), 5 (T2), 22 (T3), 36 (T4) e 42 (T5) ppt. Aproximadamente 830 indivíduos de peixes com peso médio de $1,24 \pm 0,52 \mathrm{~g}$ foram distribuídos aleatoriamente (166 peixes / tanque) em cinco tanques de concreto (cada tanque tinha $30 \times 6 \times 4$ pés $(9,1 \times 1,8 \times 1,2$ metros), com volume

*e-mail: habib5447@gmail.com; habib.ulhassan@gmail.com

Received: July 11, 2021 - Accepted: September 6, 2021 
de 19,12 litros) por 40 dias. Os peixes foram inicialmente alimentados com uma dieta contendo $42 \%$ de proteína bruta a uma taxa de $6 \%$ do seu peso corporal por dia. Os resultados mostraram que o nível de salinidade teve um efeito significativo no ganho de peso (GP), ganho de peso médio diário (GPMD), taxa de crescimento específico (TCE), taxa de conversão alimentar (TCA), taxa de sobrevivência (TS), biomassa total e índices de saúde ( $\mathrm{p}<0,05)$. O maior GP $(39,11 \pm 1,49 \mathrm{~g}), \operatorname{GPMD}(1,00 \pm 0,12 \mathrm{~g}), \operatorname{TCE}\left(8,74 \pm 0,03 \% \mathrm{~d}^{-1}\right)$ e o menor TCA $(0,96 \pm 0,20)$ foram observados com 0 tratamento T3, que foi significativamente superior em comparação com os outros tratamentos $(p<0,05)$. Entre os índices de saúde, os maiores índices hepatossomáticos e viscerossomáticos foram encontrados no tratamento T3, significativamente superior do que os demais grupos $(\mathrm{p}<0,05)$. Não foram encontradas diferenças significativas entre os tratamentos quanto à TS ( $p>0,05)$, mas a TS máxima $(98,89 \pm 0,0 \%)$ foi observada nos tratamentos T3 e T2. O nível máximo de proteína bruta $(19,99 \pm 1,4 \%)$ foi encontrado na composição bioquímica dos corpos dos jovens robalos asiáticos no grupo T3. A regressão polinomial de segunda ordem mostrou que a salinidade de 20 ppt é ótima para o melhor crescimento do robalo asiático. Assim, o presente estudo recomenda salinidade de 20 a 36 ppt para o cultivo comercial de robalo asiático em sistema de aquicultura fechado.

Palavras-chave: Lates calcarifer, aquicultura, efeitos da salinidade, sobrevivência.

\section{Introduction}

One billion people globally consumed fish, which is one of the major high-quality protein sources (Ahmad et al., 2020; Khalid et al., 2021). Asian seabass Lates calcarifer (Bloch 1790) is commonly known as "Barramundi" or "giant sea perch" or "Asian seabass" throughout the world. Asian seabass is one of the most suitable aquaculture species due to its high tolerance to broad environmental conditions, delicately flavoured tasty, nutritious meat, and fast growth rate (Haque et al., 2021; Khan et al., 2021; Hassan et al., 2021a). Asian seabass can be reached to 1.5 to $3.0 \mathrm{~kg}$ in a year when its environmental conditions are optimum, and the maximum weight has been recorded about $60 \mathrm{~kg}$. Asian seabass has sustained high demand and market price in domestic and export markets (Rao et al., 2013; Hassan et al., 2021b). Asian seabass is a hardy species that tolerates a broad salinity range from 0 to $56 \mathrm{ppt}$ salinity (FAO, 2017). Salinity is a critical environmental factor that can highly affect the physiology of aquatic organisms (Urbina and Glover, 2015). Asian seabass has wide physiological tolerances growing in marine, brackish, and freshwater (Yue et al., 2009; Anil et al., 2010; Ganzon-Naret, 2013; Venkatachalam et al., 2018). Salinity also has an antagonistic effect on growth, survival, fecundity, physiology and osmoregulation (Smith, 2003; Smith and Schindler, 2009; Anni et al., 2016). Fish at the extreme of their salinity tolerance range often exceed their ability to osmoregulate (Sampaio and Bianchini, 2002). The rapid rise in salinity disrupts physiological procedures in fish, leading to greater concentrations of cortisol in the blood (Tsuzuki et al., 2007).

The culture of Asian seabass is relatively new in Pakistan (Shah et al., 2020). The development of breeding, larviculture and farming technology is urgently needed to increase and establish the Asian seabass aquaculture. Specific management of water parameters and seed production is required for effective aquaculture practice to avoid declining wild fisheries resources (Shah et al., 2020) for excellent growth performance and successful aquaculture necessary optimum parameters. Therefore, the objective of this study was to investigate the growth performance, survival, and health status of Asian seabass with a wide range of salinities in a closed aquaculture system.

\section{Materials and Methods}

\subsection{Experimental design}

The present study was conducted at the Sindh fish hatchery near Hawke's Bay from March 2019 to Jan 2020. A total of 830 seabass juveniles $(1.24 \pm 0.52 \mathrm{~g})$ were collected from the coastal area of Sindh Sakro and stocked (166 fish/ Tank) in five treatments (T1, T2, T3, T4 and T5). Each treatment tank was $30 \times 6 \times 4$ feet containing $0,5,22,35$ and 42 ppt salinity by following Azodi et al. (2016) methods with some modifications. Tank water was regulated by blending filtered water from the ocean and freshwater. Water was exchanged for the maintenance of the water quality by up to $50 \%$ every two days. Initially fish were fed at $6 \%$ of body weight per day for 40 days, further adjusted according to the fish body on weekly basis. The extruded pellet (42.0\% crude protein) was used for manual feeding twice daily at two distinct satiation levels. After 3 hours of feeding, the extra feed was removed with a siphon. The total consumption of food was reported daily in each treatment. A 42\% CP-level diet was used using various components (Table 1 ), referred to as the entire diet/ration structure. This diet was offered regularly based on the daily wet body weight of the individuals.

\subsection{Feed formulation and preparation}

Feed ingredients were collected from the local market in Karachi and formulated as previously described by Ghosh et al. (2011). The major source of protein used in diets was fishmeal, and the levels of proteins were $42 \%$. The feed ingredients have been combined to form a dough with fish oil and water. The palletizer was carried through the dough to create the necessary pellet diet. Under dry conditions, the feed was stored in a freezer until used. The list of feed ingredients used in the experimental diets and proximate composition analysis of the formulated diets used for Asian seabass is presented in Table 1.

\subsection{Samples collection and Biochemical analysis}

The biochemical analysis of feed and fish carcass samples was carried out based on (AOAC, 2000). At the end of the experiment, five fish were removed from each tank and then dissected for collecting liver and viscera. The weight of the liver and viscera were used to calculate HSI and VSI. 
Table 1. Feed ingredients of the experimental diet and biochemical composition of the prepared diets used for Asian seabass.

\begin{tabular}{lc}
\hline \multicolumn{1}{c}{ Ingredients (\%) } & Diet (\%) \\
\hline Fish meal & 41.0 \\
Shrimp meal & 5.5 \\
Soybean meal & 24.5 \\
Squid meal & 4.4 \\
Rice bran & 7.5 \\
Bread flour & 4.4 \\
Cod liver oil & 5.4 \\
Mineral and vitamin premix & 6.0 \\
Fish protein Hydrolysate & 1.3 \\
Total & 100 \\
Biochemical composition of diet $(\%)^{1}$ & $(\%)$ \\
Crude protein ${ }^{2}$ & $41.8 \pm 0.5$ \\
Crude fiber & $9.1 \pm 0.5$ \\
Crude lipid & $8.5 \pm 0.06$ \\
ASH & $9.3 \pm 0.5$ \\
Moisture & 10.8 \\
Nitrogen-free extract & $31.30 \pm 0.5$ \\
P/E (mg crude protein $\mathrm{KJ}^{-1}$ & $14.7 \pm 0.5$ \\
Energy (kJg-1 & $24.5 \pm 0.6$ \\
\hline
\end{tabular}

Note: ${ }^{1}$ Dry matter basis (\%): mean $\pm \mathrm{SE}$, number of determinations $=5$ ${ }^{2}$ Measured as nitrogen $\times 6.25 .{ }^{3}$ Nitrogen-free extract $=100-(\%$ protein $+\%$ lipid + \% fiber + \% ash)

Crude protein $(\mathrm{CP})$ and crude lipid $(\mathrm{CL})$ were determined according to the standard method (Folch et al., 1957; AOAC, 2000). To determine moisture content, the sample was dried at $105^{\circ} \mathrm{C}$ in an oven for $24 \mathrm{~h}$ (Labostar-LG122 Tabia Espec, Osaka, Japan). The total ash content was estimated by burning the sample in a muffle furnace at $550^{\circ} \mathrm{C}$ for $3 \mathrm{~h}$.

\subsection{Water quality parameters}

Water quality parameters such as temperature, salinity, dissolved oxygen (DO), and pH were recorded daily using a celsius glass thermometer, hand-held refractometer, mobile digital DO-meter (Model: HI9146), digital pH meter, respectively. The concentrations of ammonia, alkalinity, nitrate, and nitrite were measured by following the methods of APHA (1995). Details of the water quality parameters recorded during the study period are given in Table 2 .

\subsection{Growth performance analysis}

The wet weight gain, average daily weight gain (ADWG), specific growth rate (SGR), feed conversion ratio (FCR), hepatosomatic index (HSI), viscerosomatic index (VSI), Fulton's condition factor (CF), survival rate (SR) and total biomass. Following growth parameters were calculated as described previously (Szkudlarek and Zakes, 2007; Hassan et al., 2020):

$$
\begin{aligned}
& \text { WG }=\text { Final weight }- \text { Initial weight } \\
& A D W G=(\text { Final weight }- \text { Initial weight }) / \text { Days } \\
& \text { SGR }(\%)=[(\text { Ln FBW }- \text { Ln IBW }) / \text { Day }] \times 100 \\
& \text { FCR }=\text { Food given }(g) / \text { Weight gain }(g) \\
& \text { Fulton's condition factor }(K)=\left(\text { Weight } / \text { Length }{ }^{3}\right) \times 100 \\
& \text { VSI }=\left(\begin{array}{c}
\text { Weight of visceral organs and associated }) \times 100 \\
\text { fat tissue }(g) / \text { Wet body weight }
\end{array}\right) \\
& \text { HSI }=\text { Weight of liver }(g) / \text { Empty fish weight }(g) \times 100 \\
& \text { SR }(\%)=(\text { No. of fish survived / No. of fish released }) \times 100 \\
& \text { Cannibalism }(\%)=100 \times[(\text { LS }-M-\text { LC }) / L S]
\end{aligned}
$$

Where LS is stocked at the beginning of seabass, LC is the number of fish collected at the end of the study, and $M$ is natural mortality.

$$
\text { Biomass }=\text { Average body weight } \times \text { No. of fish }
$$

\subsection{Statistical analysis}

All data were analyzed using STATISTICA V.13 software (StatSoft Inc., Tulsa, OK, USA). Residuals were tested for normality (Shapiro-Wilk test) and homogeneity of variance (plot of residuals versus predicted values). The percentages data were natural $\log (\mathrm{LN})$-transformed before analysis. The effects of different salinity group on the growth performance and health indices of Asian seabass juveniles at different culture periods were analyzed using a repeated-measures ANOVA model containing culture period (fixed repeated factor) and different salinity groups (fixed factor) main effects as well the culture period $x$ different salinity groups interaction term. Then, the model was decomposed into a series of one-way ANOVA was run to test the effects of varying salinity levels on the wet weight gain, average daily weight gain, specific growth rate, hepatosomatic index, viscerosomatic index, Fulton's condition factor, feed conversion ratio, survival rate and biomass for different culture periods. A posteriori analysis was performed using Tukey's multiple comparisons procedures. A significance level of $\mathrm{p}<0.05$ was used for all statistical tests.

\section{Results}

\subsection{Physicochemical parameters}

The mean water $\mathrm{pH}$ and temperature values were recorded, ranging from 8.10 to 8.81 and 29.40 to $29.74{ }^{\circ} \mathrm{C}$, respectively 
(Table 2). The mean value of dissolved oxygen (DO) was 7.16 to $8.16 \mathrm{mg} / \mathrm{L}$, and dissolved ammonia concentration was 0.012 to $0.072 \mathrm{mg} / \mathrm{L}$ whereas, alkalinity was between 126.1 and $162.4 \mathrm{mg} / \mathrm{L}$, nitrates were between 0.004 and $2.57 \mathrm{mg} / \mathrm{L}$ and nitrates were between 0.010 and $0.014 \mathrm{mg} / \mathrm{L}$, respectively.

\subsection{Growth performance}

The saturated repeated-measures ANOVA model revealed a significant effect on the culture period $\times$ different salinity groups interaction term $(\mathrm{p}<0.01)$. Therefore, the model was decomposed into a series of a lower-order statistical models. Our results showed that salinity level had a significant effect on the weight gain, average daily weight gain, specific growth rate total biomass and health indices $(\mathrm{p}<0.05)$ (Table 3$)$. The highest weight gain (39.11 $\pm 1.49 \mathrm{~g})$, average daily weight gain $(1.00 \pm 0.12 \mathrm{~g})$, specific growth rate $\left(8.74 \pm 0.03 \% \mathrm{~d}^{-1}\right)$ and total biomass $(6654 \pm 4.20 \mathrm{~g})$ were observed with $22 \mathrm{ppt}$ salinity treatment, which was significantly higher compared to other treatment groups $(\mathrm{p}<0.05)$. However, the growth curve was decreased with increased salinity above 36 to $42 \mathrm{ppt}$. The second-order polynomial regression showed that 20 ppt salinity is optimum for the best growth of Asian seabass.

\subsection{Feed utilization parameters}

The FCR value significantly varied among the groups ( $\mathrm{p}<0.05$, Table 3$)$. The T3 treatment group had the best FCR $(0.96 \pm 0.20)$ compared to the T1 (1.24 \pm 0.10$), \mathrm{T} 2(1.04 \pm 0.00)$ and $\mathrm{T} 4(1.23 \pm 0.10)$.

\subsection{Morphological indices}

Among the health indices, the highest hepatosomatic index and viscerosomatic index were found with $22 \mathrm{ppt}$ salinity treatment, which was significantly higher than the

Table 2. Water quality parameters of four experimental tanks at Sindh Fish Hatchery recorded during the experimental period extends from March 2019 to Jan 2020. Values are presented as mean \pm SE.

\begin{tabular}{lccccc}
\hline \multirow{2}{*}{ Water parameter } & \multicolumn{5}{c}{ Treatments } \\
\cline { 2 - 6 } & T1 (0ppt) & T2 (5ppt) & T3 (22 ppt) & T4(36 ppt) & T5 (42 ppt) \\
\hline pH & $8.10 \pm 0.24$ & $8.40 \pm 0.22$ & $8.60 \pm 0.26$ & $8.80 \pm 0.29$ & $8.81 \pm 0.28$ \\
Temperature $\left({ }^{\circ} \mathrm{C}\right)$ & $29.40 \pm 1.25$ & $29.60 \pm 1.25$ & $29.62 \pm 1.10$ & $29.74 \pm 1.31$ & $29.74 \pm 1.10$ \\
D.O $(\mathrm{mg} / \mathrm{L})$ & $8.16+1.20$ & $7.16+1.20$ & $7.95 \pm 0.07$ & $8.03 \pm 0.25$ & $7.98 \pm 0.08$ \\
Ammonia $(\mathrm{mg} / \mathrm{L})$ & $0.013 \pm 0.005$ & $0.012 \pm 0.005$ & $0.011 \pm 0.005$ & $0.072 \pm 0.112$ & $0.013 \pm 0.005$ \\
Alkalinity $(\mathrm{mg} / \mathrm{L})$ & $126.1 \pm 5.56$ & $143.1 \pm 5.56$ & $147.4 \pm 5.07$ & $152.6 \pm 5.03$ & $162.4 \pm 5.07$ \\
Nitrite $(\mathrm{mg} / \mathrm{L})$ & $0.010 \pm 0.004$ & $0.012 \pm 0.004$ & $0.013 \pm 0.005$ & $0.013 \pm 0.007$ & $0.014 \pm 0.005$ \\
Nitrate $(\mathrm{mg} / \mathrm{L})$ & $0.004 \pm 0.001$ & $2.22 \pm 0.373$ & $2.32 \pm 0.20$ & $2.418 \pm 0.48$ & $2.572 \pm 0.20$ \\
\hline
\end{tabular}

Table 3. The effect of different salinity levels $(0,5,22,36 \& 42 \mathrm{ppt})$ on growth performance, morphological indices and survival of Asian seabass. Values are presented as mean \pm SE of groups in the same row with different superscripts are significantly different ( $p>0.05$ ).

\begin{tabular}{lccccc}
\hline \multirow{2}{*}{ Attributes } & \multicolumn{3}{c}{ Salinity level } \\
\cline { 2 - 5 } & T1 (0 ppt) & T2 (5 ppt) & T3 (22 ppt) & T4(36 ppt) & T5 (42 ppt) \\
\hline Initial body weight (g) & $1.22 \pm 0.43$ & $1.22 \pm 0.43$ & $1.22 \pm 0.35$ & $1.22 \pm 0.43$ & $1.23 \pm 0.46$ \\
Final body weight (g) & $37.80 \pm 0.45^{\mathrm{b}}$ & $38.20 \pm 0.42^{\mathrm{b}}$ & $40.33 \pm 1.84^{\mathrm{a}}$ & $37.10 \pm 0.40^{\mathrm{b}}$ & $36.50 \pm 1.06^{\mathrm{b}}$ \\
Weight gain (g) & $36.38 \pm 0.02^{\mathrm{b}}$ & $37.28 \pm 0.01^{\mathrm{b}}$ & $39.11 \pm 1.49^{\mathrm{a}}$ & $36.12 \pm 0.03^{\mathrm{b}}$ & $34.28 \pm 0.39^{\mathrm{b}}$ \\
Average daily weight gain (g/day) & $0.90 \pm 0.11^{\mathrm{b}}$ & $0.94 \pm 0.09^{\mathrm{b}}$ & $1.00 \pm 0.12^{\mathrm{a}}$ & $0.89 \pm 0.08^{\mathrm{c}}$ & $0.88 \pm 0.06^{\mathrm{c}}$ \\
Specific growth rate (\%d $\left.{ }^{-1}\right)$ & $8.57 \pm 0.01^{\mathrm{b}}$ & $8.65 \pm 0.03^{\mathrm{b}}$ & $8.74 \pm 0.03^{\mathrm{a}}$ & $8.53 \pm 0.02^{\mathrm{b}}$ & $8.47 \pm 0.04^{\mathrm{c}}$ \\
Hepatosomatic index (HSI) & $1.30 \pm 0.13^{\mathrm{b}}$ & $1.30 \pm 0.32^{\mathrm{b}}$ & $1.40 \pm 0.06^{\mathrm{a}}$ & $1.30 \pm 0.12^{\mathrm{b}}$ & $1.20 \pm 0.01^{\mathrm{c}}$ \\
Viscerosomatic index (VSI) & $3.50 \pm 0.21^{\mathrm{c}}$ & $4.60 \pm 0.11^{\mathrm{b}}$ & $4.80 \pm 0.31^{\mathrm{a}}$ & $4.50 \pm 0.21^{\mathrm{b}}$ & $3.30 \pm 0.11^{\mathrm{c}}$ \\
Condition factor & $1.50 \pm 0.04^{\mathrm{a}}$ & $1.38 \pm 0.06^{\mathrm{b}}$ & $1.17 \pm 0.02^{\mathrm{c}}$ & $1.68 \pm 0.06^{\mathrm{a}}$ & $1.41 \pm 0.21^{\mathrm{b}}$ \\
Feed conversion ratio & $1.24 \pm 0.10^{\mathrm{b}}$ & $1.04 \pm 0.00^{\mathrm{c}}$ & $0.96 \pm 0.20^{\mathrm{c}}$ & $1.23 \pm 0.10^{\mathrm{b}}$ & $1.47 \pm 0.20^{\mathrm{a}}$ \\
Cannibalism (\%) & $2.40 \pm 0.00^{\mathrm{a}}$ & $0.00 \pm 0.00^{\mathrm{a}}$ & $0.00 \pm 0.00^{\mathrm{a}}$ & $1.20 \pm 0.00^{\mathrm{a}}$ & $0.00 \pm 0.00^{\mathrm{a}}$ \\
Survival rate (\%) & $97.59 \pm 0.0^{\mathrm{a}}$ & $98.79 \pm 0.0^{\mathrm{a}}$ & $99.39 \pm .0 .0^{\mathrm{a}}$ & $97.23 \pm 0.0^{\mathrm{a}}$ & $96.98 \pm 0.0^{\mathrm{a}}$ \\
Total biomass (g) & $5893 \pm 4.12^{\mathrm{c}}$ & $6113 \pm 3.59^{\mathrm{b}}$ & $6654 \pm 4.20^{\mathrm{b}}$ & $6010 \pm 22^{\mathrm{d}}$ & $5876 \pm 43^{\mathrm{a}}$ \\
\hline
\end{tabular}


other treatment groups $(p<0.05)$. The better condition factor was also found in the T3 compared to other treatments.

\subsection{Cannibalism and survival}

No significant differences were found among the treatments in terms of survival rate ( $p>0.05)$, but the maximum survival rate $(99.39 \pm 0.0 \%)$ was recorded in the T3 treatment group. The cannibalism of juveniles was noticed in the T1 and T4 treatment groups.

\subsection{Proximate composition of fish carcass}

The proximate carcass composition was calculated based on the wet weight and presented in Table 4 . The content of moisture and proteins was not significantly affected by the salinity. Conversely, the carcass content of lipid and ash significantly differed among the treatments, where lipid carcass of $\mathrm{T} 1, \mathrm{~T} 2, \mathrm{~T} 3$ was lower than the $\mathrm{T} 4$ and $\mathrm{T} 5$ treatment groups. The content of moisture and proteins in the carcass was not affected by the salinity, but the moisture content was higher in the T1 treatment group than in the other treatments. There was a positive correlation between the crude proteins in the carcass and the increase of salinity level. The maximum level of crude proteins (19.99 $1.4 \%$ ) of Asian seabass juveniles was found in the $\mathrm{T} 3$ treatment group reared at $22 \mathrm{ppt}$ salinity (Table 4 ). Ash content of the T1 treatment was $7.82 \pm 0.1$, which was significantly higher than the other treatments $(p<0.05)$.

\section{Discussion}

Asian seabass $L$. calcarifer has great commercial values compared to other marine fishes in most Southeast Asian countries, including Thailand, Taiwan, Indonesia, Malaysia, Singapore and Hong Kong. Most countries have now used this cultured species for development and research purposes in pond and cage culture systems. In this study, the means of observed physicochemical parameters had no marked variation and fall between the acceptable range for the growth and well-being of Asian seabass juveniles (Priestley et al., 2006; Hassan et al., 2021c). Kungvankij et al. (1986) found 7.5 to 8.3 water $\mathrm{pH}, 26$ to $32^{\circ} \mathrm{C}$ temperature, 4.0 to $8.0 \mathrm{mg} / \mathrm{L}$ dissolved oxygen, $<0.02 \mathrm{mg} / \mathrm{L}$ dissolved ammonia, and 10.0 to 31.0 ppt salinity are preferred for Asian seabass fry, and fingerlings reared in concrete tanks. Moreover, the nitrite and nitrate concentrations were comparatively low ( $>5 \mathrm{mg} / \mathrm{L}$ ) in the five experimental tanks of this study. It may be due to the addition of surface runoff water from rainfall bringing pollutants, including domestic sewage wastes, agriculture and industrial wastes in fish ponds, water resources used in fish culture, and ammonium wastes from fish excreta released in fish ponds (Christensen et al., 2012). Nitrate in ponds was higher than in canals because of the decomposition of ammonia from fish waste to nitrate. However, nitrate was found in low concentration, which was met the surface water quality criteria. The present results of water quality parameters were also found to be optimum for the growth of Asian seabass, as reported by Jerry (2014). Besides, Abdullah et al. (2018) showed the significant impact of dry and monsoon seasons on the water parameters, including salinity, dissolved oxygen concentrations, and the turbidity of Asian seabass culturing near Sri Tujuh lagoon the northeast coast of Peninsular Malaysia.

In this study, the optimum salinity revealed for the routine culture of seabass was $22 \mathrm{ppt}$ (T3), which was very close to the results obtained by Ercan et al. (2015). Asian seabass have been successfully cultured in the freshwater ponds in various regions of the world like in Thailand and coastal water ponds like Tahiti with salinity ranging from 10 to $35 \mathrm{ppt}$. Hence, most farmers commonly cultured Asian seabass in ponds along the sea coast with salinities ranging between 10 to $30 \mathrm{ppt}$. Euryhaline fishes undergo a crucial stage during their acclimatization in a hyperosmotic environment.

There is a rapid increase in the gill-ion fluid, followed by a rise in serum electrolytes and osmolality. In the present study, the acclimatization process for the juvenile fish was done to reduce the stress level of the fish during exposure to the different salinity treatments. The young fish were not directly introduced to the various salinity treatments. Indeed, the salinity was decreased or increased slowly to the targeted level using a dropper to avoid the startling of fish. Thus, the juvenile can survive in a wide range of salinity without affecting its mortality rate (Cotton et al., 2003). In the present study, less mortality of juveniles was found for all the treatment groups ( 0 to 42 ppt salinity), which indicates that Asian seabass juveniles can resist abrupt hyper/hypoosmotic exposure. When medium salinity fluctuations have questioned fish, the ion concentration in body fluids has altered. This phenomenon is connected with the higher exchange layer on the skin and gut, leading to higher water absorption (Shui et al., 2018).

Table 4. The whole-body proximate composition (\% of wet weight) of Asian seabass at different salinity level. Values are presented as mean \pm SE of groups in the same row with different superscripts are significantly different $(p>0.05)$.

\begin{tabular}{lccccc}
\hline \multirow{2}{*}{ Ingredients (\%) } & \multicolumn{5}{c}{ Salinity Level } \\
\cline { 2 - 5 } & T1 (0 ppt) & T2 (5 ppt) & T3 (22 ppt) & T4 (36 ppt) & T5 (42 ppt) \\
\hline Crude proteins (\%) & $18.80 \pm 1.2^{\mathrm{b}}$ & $19.03 \pm 1.2^{\mathrm{ab}}$ & $19.99 \pm 1.4^{\mathrm{a}}$ & $19.80 \pm 1.4^{\mathrm{b}}$ & $19.02 \pm 1.4^{\mathrm{ab}}$ \\
Crude lipids (\%) & $8.30 \pm 0.60^{\mathrm{ab}}$ & $8.80 \pm 0.60^{\mathrm{a}}$ & $8.40 \pm 0.8^{\mathrm{b}}$ & $8.30 \pm 0.77^{\mathrm{c}}$ & $8.29 \pm 0.77^{\mathrm{b}}$ \\
Moisture (\%) & $70.20 \pm 1.1^{\mathrm{a}}$ & $69.10 \pm 2.1^{\mathrm{a}}$ & $69.30 \pm 1.2^{\mathrm{a}}$ & $69.50 \pm 2.5^{\mathrm{a}}$ & $69.60 \pm 2.5^{\mathrm{a}}$ \\
Ash (\%) & $7.82 \pm 0.1^{\mathrm{b}}$ & $7.62 \pm 0.2^{\mathrm{b}}$ & $7.41 \pm 0.3^{\mathrm{b}}$ & $6.90 \pm 0.8^{\mathrm{a}}$ & $6.85 \pm 0.6^{\mathrm{a}}$ \\
\hline
\end{tabular}




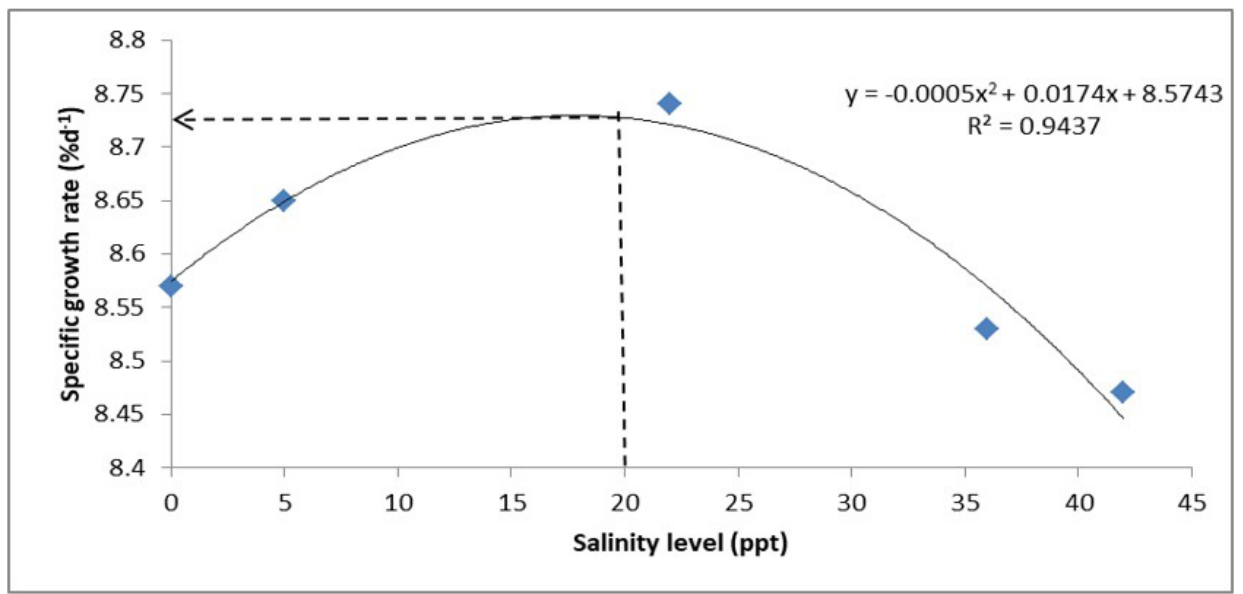

Figure 1. Second order polynomial regression between specific growth rate (SGR \%/d) and salinity levels shows that Asian seabass, 20 ppt salinity optimum for growth performance.

The significant impact of various salinity levels ranged from 0.5 to $33 \mathrm{ppt}$ on the growth and body composition of European bass Dicentrarchus labrax but the juveniles can survive in between 5 to $33 \mathrm{ppt}$ salinities (Dendrinos and Thorpe, 1985). They also observed its maximum growth rate at $30 \mathrm{ppt}$, which decreased with a decreasing salinity from 25 to $20 \mathrm{ppt}$, and even died in freshwater with 0 ppt within a few days. However, such changes in salinity levels have no impact on the proximate composition of fish body muscles. In the present study, various salinity levels affected the growth performance and survival rate, where the best growth performance and survival rate were recorded in T3 (22 ppt salinity). A previous study of Bernardino and Fernandes (2016) plotted a classical of precise growth rate (SGR) against the rising of salinity levels by second-order line regression of Asia seabass $\left(y=-0.0005 x 2+0.0174 x-8.5743 ; R^{2}=0.9437\right)$ showed a decreased growth rate at high and low salinity. According to polynomial regression, the optimum salinity is $20 \mathrm{ppt}$ estimated in the present study for the best SGR in Asian seabass (Figure 1). These results were in agreement with Bernardino and Fernandes (2016), who reported that the enhancement of salinity results in increasing the growth rate of fish up to a maximum rate than the growth curve decrease (Cotton et al., 2003).

The increasing or decreasing salinity level of the euryhaline species negatively affected the growth. This observation was in agreement with Azodi et al. (2016), who had also found that salinity is the main factor affecting fecundity, osmoregulation, growth rate, feed consumption and survival of fish. Rearing fish in high salinity conditions has the potential to suppress the appetite of the fish. Previous studies suggested that decreasing growth in increased salinity was related to the decrease in food consumption (Li et al., 2008; Partridge and Lymbery, 2008). The hyper-saline environment at 42 ppt salinity negatively affects the growth rate, oxygen consumption, histological changes in hepatopancreas and survival (Li et al., 2007). Asian seabass at an extreme salinity range often increases their ability for osmoregulation. Asian seabass juveniles reared within 0 to $36 \mathrm{ppt}$ salinity could obtained its expected specific growth rate (Partridge and Lymbery, 2008).

\section{Conclusion}

The present study concludes that the highest growth and survival of Asian seabass were observed at $22 \mathrm{ppt}$ salinity compared to the other salinity treatments. Therefore, the present study recommends 20 to $36 \mathrm{ppt}$ salinity for the commercial farming of Asian seabass under a closed aquaculture system. Using a distinct salinity would be advantageous to maximize seabass production and promote economic growth in aquaculture production.

\section{Acknowledgements}

The authors extend their appreciation to the deanship of Scientific Research at King Khalid University, Abha KSA for supporting this work under grant number (R.G.P.2/61/42). We are indebted to the Department of Zoology (MRCC), University of Karachi, for laboratory space.

\section{References}

ABDULLAH, H., RAK, A. and WEI, L., 2018 [viewed 11 July 2021]. The impacts of monsoon and dry seasons on physical water quality changes and farmed Asian seabass Lates calcarifer (Bloch, 1790) mortality at Sri Tujuh lagoon. Aquaculture, Aquarium, Conservation \& Legislation [online], vol. 11, no. 1, pp. 167-182. Available from: http://www.bioflux.com.ro/ docs/2018.167-183.pdf

AHMAD, A., KHAN, W., DAS, S.N., PAHANWAR, W.A., KHALID, S., MAHMOUD, S.A., AHMED, S., KAMAL, M., AHMED, M.S., HASSAN, U.H., ZAHOORI, S. and MAQBOOL, A., 2020. Assessment of ecto and endo parasites of Schizothorax plagiostomus inhabiting river Panjkora, Khyber Pakhtunkhwa, Pakistan. Brazilian Journal 
of Biology = Revista Brasileira de Biologia, vol. 81, no. 1, pp. 16784375. PMid:32578669.

AMERICAN PUBLIC HEALTH ASSOCIATION - APHA, 1995. Standard methods for the examination of water and wastewater. 19th ed. Washington: APHA.

ANIL, N.K., SANTOSH, B., JASMINE, S., SALEELA, K.N., GEORGE, R.M., KINGSLY, H.J., UNNIKRISHNAN, C., RAO, A.H. and SYDA, G., 2010 [viewed 11 July 2021]. Growth performance of sea bass Lates calcarifer (Bloch) in sea cages at Vizhinjam Bay along the south-west coast of India. Indian Journal of Fisheries [online], vol. 574, pp. 65-69. Available from: http://eprints.cmfri.org. in/id/eprint/7808

ANNI, I.S.A., BIANCHINI, A., BARCAROLLI, I.F., VARELA, A.S., ROBALDO, R.B., TESSER, M.B. and SAMPAIO, L.A., 2016. Salinity influence on growth, osmoregulation and energy turnover in juvenile pompano Trachinotus marginatus Cuvier 1832. Aquaculture, vol. 455, pp. 63-72. http://dx.doi.org/10.1016/j. aquaculture.2016.01.010.

ASSOCIATION OF OFFICIAL AGRICULTURAL CHEMISTS - AOAC, 2000. Official methods of analysis: coffee and tea. 17th ed. Gaithersburg: AOAC.

AZODI, M., BAHABADI, M.N., MORSHEDI, V., EBRAHIMI, H. and HAMEDI, S., 2016 [viewed 11 July 2021]. The effects of different levels of water salinity on growth, feeding performance, body composition and physiologica responses in Asian sea bass (Lates calcarifer). Journal of Fisheries Science and Technology [online], vol. 5, no. 1, pp. 99-111. Available from: http://jfst.modares. ac.ir/article-6-9513-en.html

BERNARDINO, R.J. and FERNANDES, C. 2016. Growth performance for European sea bass fingerlings, Dicentrarchus labrax, reared at different salinities. In: IMMR International Meeting on Marine Research, 2016, Peniche, Portugal. Peniche: Marine and Environmental Sciences Centre. https://doi.org/10.3389/conf. FMARS.2016.04.00031.

CHRISTENSEN, V.G., LEE, K.E., MCLEES, J.M. and NIEMELA, S.L., 2012. Relations between Retired Agricultural Land, Water Quality, and Aquatic-Community Health, Minnesota River Basin. Journal of Environmental Quality, vol. 41, no. 5, pp. 1459-1472. http:// dx.doi.org/10.2134/jeq2011.0468. PMid:23099937.

COTTON, C.F., WALKER, R.L. and RECICAR, T.C., 2003. Effects of temperature and salinity on growth of juvenile black sea bass, with implications for aquaculture. North American Journal of Aquaculture, vol. 65, no. 4, pp. 330-338. http://dx.doi. org/10.1577/C02-037.

DENDRINOS, P. and THORPE, J.P., 1985. Effects of reduced salinity on growth and body composition in the European bass Dicentrarchus labrax (L.). Aquaculture, vol. 49, no. 3-4, pp. 333-358. http:// dx.doi.org/10.1016/0044-8486(85)90090-0.

ERCAN, E., AĞRAL, N. and TARKAN, A.S., 2015. The effects of salinity, temperature and feed ratio on growth performance of european sea bass in the water obtained through reverse osmosis system and a natural river. Pakistan Journal of Zoology, vol. 47, no. 3, pp. 625-633.

FOLCH, J., LEES, M. and STANLEY, G.S., 1957. A simple method for the isolation and purification of total lipides from animal tissues. The Journal of Biological Chemistry, vol. 226, no. 1, pp. 497-509. http://dx.doi.org/10.1016/S0021-9258(18)64849-5. PMid:13428781.

FOOD AND AGRICULTURE ORGANIZATION OF THE UNITED NATIONS - FAO, 2017 [viewed 24 February 2017]. Fishstat Plus Version 2.30 [online]. Rome: FAO Fisheries Department, Fishery Information, Data and Statistics Unit. Available from: http:// www.fao.org./fi/statist/FISOFT/FISHPLUS
GANZON-NARET, E.S., 2013 [viewed 11 July 2021]. Growth response and feed intake of Lates calcarifer to four different dietary protein levels with green pea (Pisum sativum) under controlled laboratory. ABAH Bioflux [online], vol. 52, pp. 137-144. Available from: http://www.abah.bioflux.com.ro/docs/2013.137-144

GHOSH, D., SATHIANANDAN, T.V. and VIJAYAGOPAL, P., 2011. Feed Formulation Using Linear Programming for Fry of Catfish, Milkfish, Tilapia, Asian Sea Bass, and Grouper in India. Journal of Applied Aquaculture, vol. 23, no. 1, pp. 85-101. http://dx.doi. org/10.1080/10454438.2011.549781.

HAQUE, M.A., HOSSAIN, M.I., AFTABUDDIN, S., HABIB, A. and SIDDIQUE, M.A.M., 2021. First onboard fertilization of Asian seabass, Lates calcarifer: effects of egg stocking density on the fertilization, hatching and survival rate. Scientific American, vol. 12, e00841.

HASSAN, H.U., ALI, Q.M., RAHMAN, M.A., KAMAL, M., TANJIN, S., FAROOQ, U., MAWA, Z., BADSHAH, N., MAHMOOD, K., HASAN, M.R., GABOOL, K., RIMA, F.A., ISLAM, M.A., RAHMAN, O. and HOSSAIN, M.Y., 2020. Growth pattern, condition and prey-predator status of 9 fish species from the Arabian Sea (Baluchistan and Sindh), Pakistan. Egyptian Journal of Aquatic Biology and Fisheries, vol. 24, no. 4, pp. 281-292. http://dx.doi. org/10.21608/ejabf.2020.97439.

HASSAN, H.U., ALI, Q.M., AHMAD, N., MASOOD, Z., HOSSAIN, M.Y., GABOL, K., KHAN, W., HUSSAIN, M., ALI, A., ATTAULLAH, M. and KAMAL, M., 2021a. Assessment of growth characteristics, the survival rate and body composition of Asian Sea bass Lates calcarifer (Bloch, 1790) under different feeding rates in closed aquaculture system. Saudi Journal of Biological Sciences, vol. 28, no. 2, pp. 1324-1330. http://dx.doi.org/10.1016/j.sjbs.2020.11.056. PMid:33613062.

HASSAN, H.U., ALI, Q.M., KHAN, W., MASOOD, Z., ABDEL-AZIZ, M.F.A., SHAH, M.I.A., GABOL, K., WATTOO, J., MAHMOOD CHATTA, A., KAMAL, M., ZULFIQAR, T. and HOSSAIN, M.Y., 2021b. Effect of feeding frequency as a rearing system on biological performance, survival, body chemical composition and economic efficiency of Asian Seabass Lates calcarifer (Bloch, 1790) reared under controlled environmental conditions. Saudi Journal of Biological Sciences, vol. 28, no. 12, pp. 7360-7366. http://dx.doi. org/10.1016/j.sjbs.2021.08.031. PMid:34867038.

HASSAN, H.U., ALI, Q.M., SIDDIQUE, M.A.M., HASAN, M.R. and HOSSAIN, M.Y., 2021. Effects of Dietary Protein Levels On Growth, Nutritional Utilization,Carcass Composition and Survival of Asian Seabass Lates calcarifer (Bloch, 1790) Fingerlings Rearing in Net Cages. Thalassas: An International Journal of Marine Sciences. https://doi.org/10.1007/s41208-021-00371-8.

JERRY, D.R., 2014. Biology and culture of Asian Seabass Lates calcarifer. Boca Raton: Taylor \& Francis.

KHALID, S., KHANB, W., DAS, S.N., AHMAD, A., MEHMOOD, S.A., PAHANWAR, W.A., AHMED, S., KAMAL, M., WAQAS, M., WAQAS, R.M., HASSAN, U.H., ZAHOOR, S. and MAQBOOL, A., 2021. Evaluation of ecto and endo parasitic fauna of Schizothorax plagiostomus inhabitants of river Swat, Khyber Pakhtun Khwa, Pakistan. Brazilian Journal of Biology = Revista Brasileira de Biologia, vol. 81, no. 1, pp. 98-104. http://dx.doi.org/10.1590/15196984.222215. PMid:32578670.

KHAN, M.S.K., SALIN, K.R., YAKUPITIYAGE, A. and SIDDIQUE, M.A.M., 2021. Effect of stocking densities on the growth performance, cannibalism and survival of Asian seabass Lates calcarifer (Bloch, 1790) fry in different nursery rearing system. Aquaculture Research, vol. 52, no. 11, pp. 5332-5339. http:// dx.doi.org/10.1111/are.15403. 
KUNGVANKIJ, P., TIRO, L.B., PUDADERA, B.J.J.R. and POTESTA, I.O., 1986. Biology and culture of seabass (Lates calcarifer). Bangkok: NACA/RLCP, 70 p. NACA Training Manual Series, no. 3.

LI, E., CHEN, L., ZENG, C., YU, N., XIONG, Z., CHEN, X. and QIN, J.G., 2008. Comparison of digestive and antioxidant enzymes activities, haemolymph oxyhemocyanin contents and hepatopancreas histology of white shrimp, Litopenaeus vannamei at various salinities. Aquaculture, vol. 274, no. 1, pp. 80-86. http://dx.doi.org/10.1016/j.aquaculture.2007.11.001.

LI, E.C., CHEN, L.Q., ZENG, C., CHEN, X.M., YU, N., LAI, Q.M. and QIN, J.G., 2007. Growth, body composition, respiration and ambient ammonia nitrogen tolerance of the juvenile white shrimp, Litopenaeus vannamei, at different salinities. Aquaculture, vol. 265, no. 1-4, pp. 385-390. http://dx.doi.org/10.1016/j. aquaculture.2007.02.018.

PARTRIDGE, G.J. and LYMBERY, A.J., 2008. The effect of salinity on the requirement for potassium by barramundi (Lates calcarifer) in saline groundwater. Aquaculture, vol. 278, no. 1-4, pp. 164-170. http://dx.doi.org/10.1016/j.aquaculture.2008.03.042.

PRIESTLEY, S.M., STEVENSON, A.E. and ALEXANDER, L.G., 2006. The influence of feeding frequency on growth and body condition of the common goldfish (Carassius auratus). Nutrition Journal, vol. 136, no. 7, suppl., pp. 1979S-1981S. http://dx.doi.org/10.1093/ jn/136.7.1979S. PMid:16772472.

RAO, G.S., JOSEPH, I., PHILIPOSE, K.K. and MOJJADA, S.K., 2013 [viewed 11 July 2021]. Cage aquaculture in India [online]. Kochi: Central Marine Fisheries Research Institute, 233 p. Available from: http://eprints.cmfri.org.in/id/eprint/11222

SAMPAIO, L.A. and BIANCHINI, A., 2002. Salinity effects on osmoregulation and growth of the euryhaline flounder Paralichthys orbignyanus. Journal of Experimental Marine Biology and Ecology, vol. 269, no. 2, pp. 187-196. http://dx.doi. org/10.1016/S0022-0981(01)00395-1.

SHAH, S.B.H., YONGTONG, M., NAREJO, N.T., JARWARC, A., OADD, S., ALIA, M., LIA, Y. and NISARA, U., 2020. Economic analysis of Barramundi (Lates calcarifer) (Bloch 1790), in Pakistan and opportunities for its aquaculture development. Indian Journal of Geo-Marine Sciences, vol. 49, no. 8, pp. 1425-1434.
SHUI, C., SHI, Y., HUA, X., ZHANG, Z., ZHANG, H., GENHAI, L.U. and XIE, Y., 2018. Serum osmolality and ions, and gill $\mathrm{Na}^{+} / \mathrm{K}^{+}$-ATPase of spottedtail goby Synechogobius ommaturus (R.) in response to acute salinity changes. Aquaculture and Fisheries, vol. 3, no. 2, pp. 79-83. http://dx.doi.org/10.1016/j.aaf.2018.03.002.

SMITH, V.H. and SCHINDLER, D.W., 2009. Eutrophication science: where do we go from here. Trends in Ecology \&'Evolution, vol. 24, no. 4, pp. 201-207. http://dx.doi.org/10.1016/j.tree.2008.11.009. PMid:19246117.

SMITH, V.H., 2003. Eutrophication of freshwater and coastal marine ecosystems a global problem. Environmental Science and Pollution Research International, vol. 10, no. 2, pp. 126-139. http://dx.doi.org/10.1065/espr2002.12.142. PMid:12729046.

SZKUDLAREK, M. and ZAKES, Z., 2007. Effect of stocking density on survival and growth performance of pikeperch (Sander lucioperca) larvae under controlled conditions. Aquaculture International, vol. 15, no. 1, pp. 67-81. http://dx.doi.org/10.1007/ s10499-006-9069-7.

TSUZUKI, M.Y., OGAWA, K., STRÜSSMANN, C.A., MAITA, M., TAKASHIMA, F. and MELO, C.M.R., 2007. The significance of cortisol on acclimation to salinity in pejerrey Odontesthes bonariensis. Arquivo Brasileiro de Medicina Veterinária e Zootecnia, vol. 59, no. 5, pp. 1301-1307. http://dx.doi.org/10.1590/S0102-09352007000500030.

URBINA, M.A. and GLOVER, C.N., 2015. Effect of salinity on osmoregulation, metabolism and nitrogen excretion in the amphidromous fish, inanga (Galaxias maculatus). Journal of Experimental Marine Biology and Ecology, vol. 473, pp. 7-15. http://dx.doi.org/10.1016/j.jembe.2015.07.014.

VENKATACHALAM, S., KANDASAMY, K., KRISHNAMOORTHY, I. and NARAYANASAMY, R., 2018. Survival and growth of fish (Lates calcarifer) under integrated mangrove aquaculture and open aquaculture systems. Aquaculture, vol. 9, pp. 18-24. http:// dx.doi.org/10.1016/j.aqrep.2017.11.004.

YUE, G.H., ZHU, Z.Y., LO, L.C., WANG, C.M., LIN, G., FENG, F., PANG, H.Y., LI, J., GONG, P., LIU, H.M., TAN, J., CHOU, R., LIM, H. and ORBAN, L., 2009. Genetic variation and population structure of Asian seabass (Lates calcrifer) in the Asia Pacific region. Aquaculture, vol. 293, no. 1-2, pp. 22-28. http://dx.doi. org/10.1016/j.aquaculture.2009.03.053. 